\section{Regenerating Plants from in Vitro Culture of Black Locust Cotyledon and Leaf Explants}

\section{Arrillaga ${ }^{1}$}

Departamento de Biología Vegetal, Facultad de Farmacia, Universitat de Valencia, Avenida Vicent Andres Estelles s/n, 46100-Burjasot, Valencia, Spain

\section{S.A. Merkle \\ Daniel B. Warnell School of Forest Resources, University of Georgia, Athens, GA 30602}

Additional index words. Robinia pseudoacacia, tissue culture, illumination conditions, organic $\mathrm{N}$ sources, organogenesis

Abstract. A protocol to achieve efficient plant regeneration from juvenile black locust (Robinia pseudoacacia L.) explants is described. Direct adventitious shoots were induced from cotyledon explants on woody plant medium containing $22.2 \mu \mathrm{M}$ BA and $0.4 \mu \mathrm{M} 2,4$ D. Shoots developed and new shoots were induced when the explants were transferred to medium without growth regulators. The effect of dark incubation on shoot regeneration from cotyledons indicated that $\mathbf{1 5}$ days of darkness resulted in a high regeneration frequency $(91.7 \%)$. Adventitious shoot formation also was induced from sections of in vitro-derived leaves cultured in darkness on Murashige and Skoog medium supplemented with $4.4 \mu \mathrm{M}$ BA and 24.6 $\mu \mathrm{M}$ IBA. A shoot regeneration frequency of $89 \%$ was obtained when explants were subcultured on a medium containing 4.4 $\mu \mathrm{M}$ BA and $0.5 \mu \mathrm{M}$ IAA. Shoots were rooted on Schenk and Hildebrandt medium with or without IBA. Plantlets were acclimatized and grown in the greenhouse. Chemical names used: $N$-(phenylmethyl)$1 H$-purin-6-amine (BA); 2,4-dichlorophenoxyacetic acid (2,4-D); indole-3-acetic acid (IAA); indole-3-butyric acid (IBA).

Black locust, an N-fixing leguminous forest tree species native to the eastern United States, is cultivated extensively as an ornamental tree in many parts of the world. This species is one of the leading candidates for woody biomass energy plantations in the United States (Ranney et al., 1988) and Europe (Mitchell, 1988). Black locust generally is propagated by seeds and via root or stem cuttings. Three in vitro regeneration pathways have been reported: axillary bud elongation and multiplication from nodal or bud explants (Barghchi, 1987; Chalupa, 1983,1987; Davis and Keathley, 1987, 1988); differentiation of adventitious shoots from callus cultures, leaf disks, or hypocotyl explants (Brown and Sommer, 1982; Davis and Keathley, 1985; Han and Keathley, 1989); and somatic embryogenesis (Merkle and Wiecko, 1989).

One of the protocols for Agrobacteriummediated gene transfer in plants involves in-

\footnotetext{
Received for publication 23 Nov. 1992. Accepted for publication 22 Apr. 1993. This research was supported by the Conselleria de Cultura, Educaci6n y Ciencia de la Generalitat Valenciana, Spain, as a grant to I.A and by the U.S. Dept. of Energy, contract no. DE-AC05-840R21400. The cost of publishing this paper was defrayed in part by the payment of page charges. Under postal regulations, this paper therefore must be hereby marked advertisement solely to indicate this fact.

'Current address: Daniel B. Warnell School of Forest Resources, Univ. of Georgia, Athens, GA 30602.
}

oculating leaf-disk explants with the bacterium and regenerating transformed shoots on a selection medium (Horsch et al., 1985). Davis and Keathley (1985) and Han and Keathley (1989) reported low shoot regeneration from black locust leaf disks and hypocotyl-derived callus. Therefore, developing an efficient black locust regeneration system may be a route for genetic transformation. In this paper, we report on experiments in which plantlets were regenerated from black locust cotyledon and in vitro-derived leaf explants.

Plant material. Mature black locust pods were collected in Sept. 1991 from Family 698 members that were growing in a range-wide planting in Greene County, Ga. Family 698 was derived from open-pollinated seeds collected in 1981 from a tree growing in a natural stand in Tallapoosa County, Ala. Seeds were removed from pods and stored at $4 \mathrm{C}$ until used. Before disinfestation, seeds were scarified with concentrated $\mathrm{H}_{2} \mathrm{SO}_{4}$ for $20 \mathrm{~min}$ and rinsed with running tap water for $20 \mathrm{~min}$. For surface disinfestation, seeds were immersed in the following solutions: $70 \%$ ethanol (30 sec), $10 \%$ Roccal (National Laboratories, Montvale, N.J.) (5 min), 100\% Clorox (5.25\% sodium hypochlorite) (5 $\mathrm{min})$, a sterile water rinse (3 min), $0.01 \mathrm{M} \mathrm{HCl}$ (3 min), and three additional sterile water rinses ( $3 \mathrm{~min}$ each). Then, seeds were imbibed overnight in sterile

\section{Material and Methods}

distilled water. After imbibition, seeds were surface disinfested again as described above, but $50 \%$ Clorox was substituted for fullstrength Clorox. Seedcoats were removed and embryos were germinated in vitro or used as a source of cotyledon explants. Germinated embryos were used to initiate shoot proliferation cultures that, in turn, were used as a source of leaf explants (see below). For germination, embryos were cultured for 30 days in tubes containing $20 \mathrm{ml}$ of a sterile solution of $3 \%$ sucrose with $0.7 \%$ Phytagar (Gibco, LifeTechnologies, Grand Island, N.Y.). To initiate shoot proliferation, shoot-tips isolated from the germinants were cultured for 30 days on medium containing Schenk and Hildebrandt (SH) macro salts (Schenk and Hildebrandt, 1972), Murashige and Skoog (MS) micro salts (Murashige and Skoog, 1962), Gresshoff and Doy (GD) vitamins (Gresshoff and Doy, 1972), $4.4 \mu \mathrm{M} \mathrm{BA}, 3 \%$ sucrose, and $0.7 \%$ Phytagar (SH medium).

Cotyledon culture. Cotyledons were excised from the embryo axis and distal and proximal ends were cut off. Cotyledon sections $(\approx 4 \mathrm{~mm}$ long) were cultured in $60 \times 15$ $\mathrm{mm}$ petri plates containing $10 \mathrm{ml}$ basal medium (BM) consisting of woody plant medium (WPM) (Lloyd and McCown, 1980) salts, GD vitamins, $3 \%$ sucrose, and $1 \mathrm{~g} \cdot$ liter $^{-1}$ each of casein hydrolysate $(\mathrm{CH})$ and myo-inositol. The $\mathrm{pH}$ was adjusted to 5.7, and the medium was solidified with $0.8 \%$ Phytagar before being autoclaved for $20 \mathrm{~min}$ at $120 \mathrm{C}$. BM was supplemented with $0.4,4.4$, or $22.2 \mu \mathrm{M} \mathrm{BA}$ combined with $0.5,5.4$, or $26.8 \mu \mathrm{M}$ 1-naphthaleneacetic acid (NAA) or $0.4,4.5$, or $22.6 \mu \mathrm{M}$ 2,4-D. Three explants, adaxial surface down, were inoculated per plate and five plates were used for each treatment. Cultures were incubated under a 16 -h photoperiod $\left(100 \mu \mathrm{mol} \cdot \mathrm{m}^{-2} \cdot \mathrm{s}^{-1}\right)$ provided by cool-white fluorescent lamps (Sylvania F20T12/cool white; GTE Products Corp., Danvers, Mass.) or in darkness at $26 \pm$ $2 \mathrm{C}$. In a second experiment, the effect of dark incubation was tested. Cotyledonsections were cultured on BM supplemented with $22.2 \mu \mathrm{M}$ BA and $0.4 \mu \mathrm{M} 2,4-\mathrm{D}$. Five dark pretreatments were used, during which culture plates (four plates with three explants each) were incubated in darkness for $0,5,15$, or 30 days and subsequently transferred to a $16-\mathrm{h}$ photoperiod. For the control treatment, cotyledons were maintained in darkness for the duration of the experiment. In both experiments, explants were transferred to BM without growth regulators after 45 days of culture, and morphogenic responses were recorded after 90 days.

Leaf culture. Leaf segments ( $\approx 3 \mathrm{~mm}$ long), excised from the in vitro-proliferated shoots produced as described above, were cultured in $100 \times 15-\mathrm{mm}$ petri plates with $25 \mathrm{ml} \mathrm{BM}$ consisting of MS salts, GD vitamins, 3\% sucrose, and $0.8 \%$ Phytagar. The effect of organic $\mathrm{N}$ was tested by adding $\mathrm{CH}\left(1 \mathrm{~g} \cdot\right.$ liter $\left.^{-1}\right)$, glutamine (10 or $20 \mathrm{~mm}$ ), or no organic $\mathrm{N}$ to the medium. Both $\mathrm{N}$ sources were added to the medium before autoclaving. Initially, the medium was supplemented with $4.4 \mu \mathrm{MBA}$ and either 9.8 or $24.6 \mu \mathrm{M}$ IBA. Four explants, 
abaxial surface down, were cultured per plate and six plates were used for each treatment. After 30 days, explants were subcultured to the same BM without growth regulators or supplemented with $4.4 \mu \mathrm{M}$ BA and $0.6 \mu \mathrm{M}$ IAA and incubated for 60 days. All plates were placed in darkness at $26 \pm 2 \mathrm{C}$.

Rooting and transfer to potting mix. To induce rooting, cotyledon- and leaf-derived shoots $>1 \mathrm{~cm}$ long were excised and cultured under a 16-h photoperiod in tubes containing $20 \mathrm{ml}$ of Phytagar-solidified SH medium without growth regulators. The effect of $2.5 \mu \mathrm{M}$ IBA on rooting also was tested on shoots regenerated from leaf explants. After 60 days, rooted plants were transplanted to pots containing Peat-lite mix (Conrad Fafard, Agawan, Mass.). Subsequently, the plants were acclimatized for 2 months in a controlled-environment room to ambient relative humidity and transferred to the greenhouse.

Statistical analysis. All experiments were conducted twice using a completely random design. The significance of treatment effects on the caulogenic response (percentage of caulogenic explants and mean number of shoots per explant) was determined using analysis of variance. The effect of dark pretreatment duration on these responses was analyzed using polynomial regression [Systat 5.2 (Systat, 1992) and Super ANOVA 1.01 (Abacus Concepts, 1989) software]. Percentage data were subjected to arcsin transformation before statistical analysis. Variation between treatment means was analyzed using Tukey's (1953) procedure.

\section{Results and Discussion}

Cotyledon cultures. In 5 days, explants had enlarged and elongated. Morphogenic responses required the presence of growth regulators in the culture medium. Callus, roots, and shoots formed within 15 to 20 days after culture initiation. In general, darkness increased callus and root formation, and BA levels $>0.4$ $\mu \mathrm{M}$ inhibited this organogenic response (data not shown). In most cases, shoot formation occurred directly from intact surfaces and cut areas of the explants (Fig. 1). Occasionally, indirect shoot organogenesis, via callus, was observed. Transferring explants to a medium without growth regulators induced additional shoots to develop.

Dark incubation significantly enhanced caulogenesis (percentage of explants forming shoots and mean number of shoots per explant) on cotyledons (Tables 1 and 2). Analysis of variance for both responses also showed a significant three-way interaction among auxin type, auxin concentration, and BA concentration (Table 2). Thus, irrespective of illumination conditions, BA levels $>0.4 \mu \mathrm{M}$ increased caulogenic percentages from explants cultured on media containing the lowest auxin concentration $(0.5 \mu \mathrm{M}$ NAA or $0.4 \mu \mathrm{M} 2,4-\mathrm{D})$. This promotive effect was not altered significantly by higher NAA concentrations. In contrast, the highest 2,4-D concentration $(22.6 \mu \mathrm{M})$ drastically reduced the caulogenic response $(10.0 \%$ vs. $56.6 \%)$ when cotyledons were cul- tured with $22.2 \mu \mathrm{M}$ BA (Table 1). In the same way, none of the BA and NAA combinations tested significantly affected the mean number of shoots per explant, while combinations of BA and 2,4-D (4.4 and 22.6 or 22.2 and $4.5 \mu \mathrm{M}$, respectively) significantly lowered this number compared to that obtained in the presence of $0.4 \mu \mathrm{M} 2,4-\mathrm{D}$ (1.1 vs. 7.8 and 3.0 vs. 8.0 shoots) (Table 1). Shoot length was variable and ranged from 0.5 to $8 \mathrm{~cm}$ (data not shown). Shoots grown in darkness were etiolated and about six times longer than those grown in light.

The effect of darkness of various durations on adventitious shoot formation from cotyledons was best described by a cubic model $(P \leq$ $0.0015, r^{2}=60.1 \%$ ) for the caulogenic re-

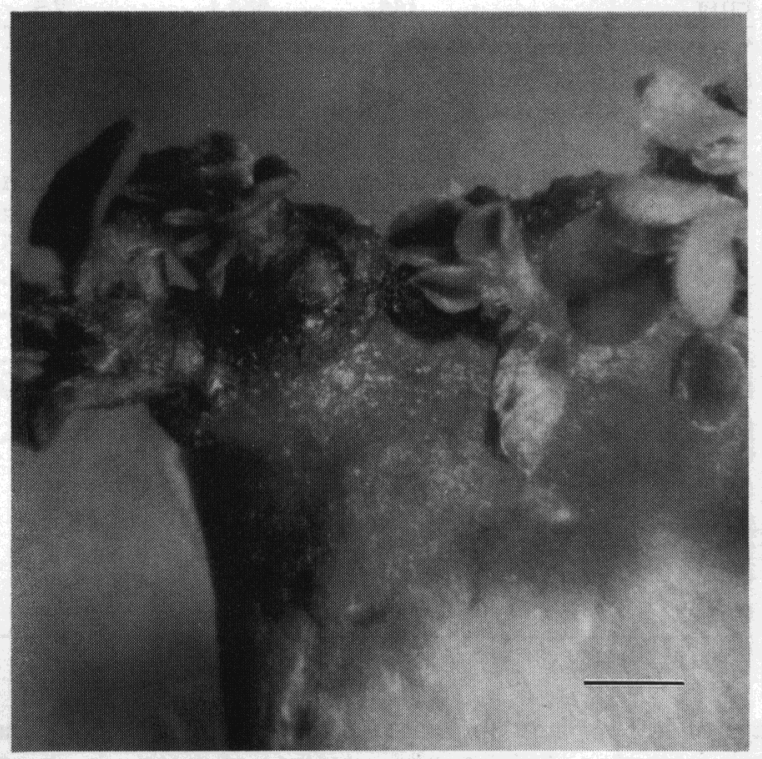

Fig. 1. Adventitious shoot formation on a black locust cotyledon explant cultured under a 16-h photoperiod on woody plant medium. $\mathrm{Bar}=1 \mathrm{~mm}$.

Table 1. Effect of growth regulators and illumination conditions on the caulogenic response of black locust cotyledon cultures. Culture time was 90 days. Values are means of five experimental replications with three explants each.

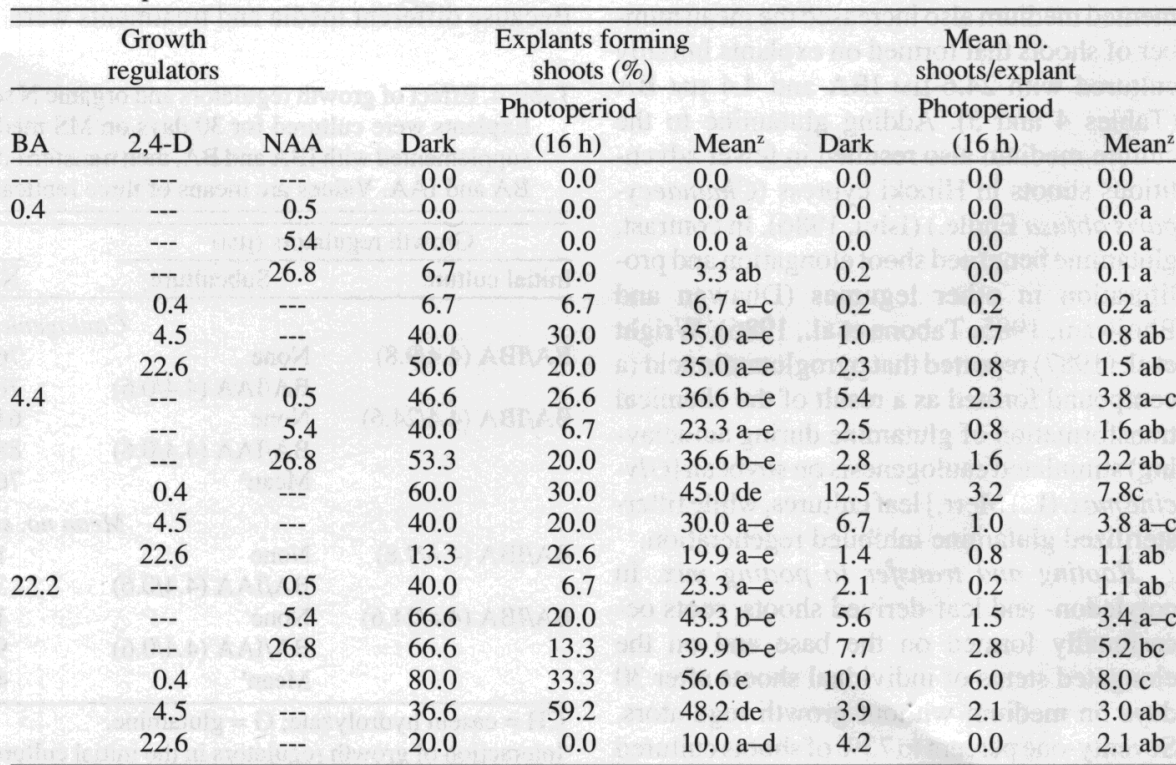

${ }^{2}$ Interaction of auxin type $\times$ auxin concentration $\times$ BA concentration. Mean separation in columns by Tukey's test $(P \leq 0.05)$. Treatments without growth regulators were omitted from the analysis. 
Table 2. Analysis of variance for Table 1 data. $^{\mathrm{z}}$

\begin{tabular}{lrcr}
\hline \hline & & \multicolumn{2}{c}{ Mean square } \\
\cline { 3 - 4 } $\begin{array}{l}\text { Source of } \\
\text { variation }\end{array}$ & df & $\begin{array}{c}\text { Caulogenesis } \\
(\%)\end{array}$ & $\begin{array}{c}\text { Mean no. } \\
\text { shoots }\end{array}$ \\
\hline Photoperiod (A) & 1 & $12792.3^{* *}$ & $278.3^{* *}$ \\
Auxin typc (B) & 1 & $3411.8^{*}$ & $65.8^{* *}$ \\
Auxin level (C) & 2 & $308.6^{\text {Ns }}$ & $40.3^{*}$ \\
BA level (D) & 2 & $7713.6^{* *}$ & $202.7^{* *}$ \\
A $\times$ B & 1 & $1061.9^{\text {Ns }}$ & $13.8^{\text {Ns }}$ \\
A $\times$ C & 2 & $154.0^{\text {Ns }}$ & $3.7^{\text {Ns }}$ \\
A $\times$ D & 2 & $1285.0^{\text {Ns }}$ & $52.2^{* *}$ \\
B $\times$ C & 2 & $1526.1^{\text {Ns }}$ & $80.9^{* *}$ \\
B $\times$ D & 2 & $2086.7^{*}$ & $3.0^{\text {Ns }}$ \\
C $\times$ D & 4 & $1728.8^{*}$ & $33.4^{* *}$ \\
A $\times$ B $\times$ C & 2 & $677.8^{\text {ss }}$ & $7.9^{\text {Ns }}$ \\
A $\times$ B $\times$ D & 2 & $1128.0^{\text {Ns }}$ & $13.2^{\text {ss }}$ \\
A $\times$ C $\times$ D & 4 & $690.8^{\text {Ns }}$ & $18.2^{\text {ss }}$ \\
B $\times$ C $\times$ D & 4 & $1991.6^{* *}$ & $43.7^{* *}$ \\
A $\times$ B $\times$ C $\times$ D & 4 & $804.2^{\text {Ns }}$ & $7.3^{\text {Ns }}$ \\
Error & 144 & 483.1 & 9.4 \\
\hline
\end{tabular}

${ }^{2}$ Treatments without growth regulators were omitted from the analysis.

ss,",**Nonsignificant or significant at $P \leq 0.05$ or 0.01 , respectively.

Table 3. Effect of dark incubation on shoot formation in black locust cotyledon cultures. Cotyledons were cultured on woody plant medium supplemented with $22.2 \mu \mathrm{M}$ BA and $0.4 \mu \mathrm{M} 2,4-\mathrm{D}$ for 45 days and then transferred to medium without growth regulators. Values are means of four replications with three explants each. Data were recorded after 90 days.

\begin{tabular}{lcc}
\hline $\begin{array}{l}\text { Dark incubation } \\
\text { (days) }\end{array}$ & $\begin{array}{c}\text { Caulogenic } \\
\text { explants }(\%)\end{array}$ & $\begin{array}{c}\text { Mean no. shoots/ } \\
\text { explant } \pm \text { sD }\end{array}$ \\
\hline 0 & 25.0 & $2.0 \pm 1.6$ \\
5 & 50.0 & $2.4 \pm 1.7$ \\
15 & 91.7 & $6.6 \pm 0.8$ \\
30 & 75.0 & $2.5 \pm 0.8$ \\
90 & 75.0 & $4.5 \pm 2.0$ \\
Contrast & $\mathrm{C}$ & NS \\
\hline
\end{tabular}

${ }^{\text {ss Nonsignificant; } \mathrm{C}=\text { cubic. }}$
The percentage of leaf explants forming shoots and the mean number of shoots per explant significantly decreased on media containing glutamine (Tables 4 and 5). Irrespective of the organic $\mathrm{N}$ source, adding $4.4 \mu \mathrm{m} \mathrm{BA}$ and $0.6 \mu \mathrm{m} \mathrm{IAA}$ to the subculture medium significantly enhanced the caulogenic response (35.3\% vs. $58.7 \%)$. This BA- and IAA- supplemented medium also increased the mean number of shoots that formed on explants initially (Tables 4 and 5). Adding glutamine to the culture medium also resulted in fewer adventitious shoots in Hinoki cypress (Chamaecyparis obtusa Endle.) (Ishii, 1986). In contrast, glutamine benefited shoot elongation and proliferation in other legumes (Dhawan and Bhojwani, 1985; Tabone et al., 1986). Wright et al. (1987) reported that pyroglutamic acid (a compound formed as a result of the chemical transformation of glutamine during autoclaving) stimulated caulogenesis on soybean [Glycine $\max$. (L.) Merr.] leaf cultures, while filtersterilized glutamine inhibited regeneration.

Rooting and transfer to potting mix. In cotyledon- and leaf-derived shoots, roots occasionally formed on the base and on the elongated stems of individual shoots after 30 days on medium without growth regulators. Seventy-one percent to $73 \%$ of shoots cultured on SH medium without growth regulators rooted after 60 days. Adding $2.5 \mu \mathrm{M}$ IBA to the cultured with $24.6 \mu \mathrm{M} \mathrm{IBA}$ and $4.4 \mu \mathrm{M} \mathrm{BA}$ rooting medium slightly increased the percentage of rooting in shoots obtained from leaf-explant cultures $(83.9 \%)$. The mean number of roots per rooted shoot was variable, ranging from 1 to 6 . All transplants survived during acclimatization.

Our study achieved direct caulogenesis from black locust cotyledon and leaf explants. Because different media and treatments were used, the results from the two groups of explants are not comparable. The procedures described herein improved the number of caulogenic explants obtained compared with those previously obtained with leaf (Davis and Keathley, 1985) or hypocotyl (Han and Keathley, 1989) explants of this species. Differences could be attributed to the genotype, illumination conditions, and culture media used. The higher shoot regeneration frequency reported here should be useful in experiments to produce transgenic black locust plants.

\section{Literature Cited}

Abacus Concepts. 1989. SuperANOVA 1.01. Abacus Concepts, Berkeley, Calif.

Barghchi, M. 1987. Mass clonal propagation in vitro of Robinia pseudoacacia L. (black locust) cv. Jaszkiseri. Plant Sci. 53: 183-189.

Barwale, U.B., H.R. Kerns, and J.M. Widholm. 1986. Plant regeneration from callus cultures of several soybean genotypes via embryogenesis

Brown, C.L. and H.E. Sommer. 1982. Vegetative propagation of dicotyledonous trees, p. 109149. In: J.M. Bonga and D.J. Durzan (eds.). Tissue culture in forestry. Martinus Nijhoff, Junk Publishers, The Hague, The Netherlands.

Chalupa, V. 1983. In vitro propagation of willows (Salix spp.), European mountain-ash (Sorbus aucuparia L.) and black locust (Robinia pseudoacacia L.). Biol. Plant. 25:305-307.

Chalupa, V. 1987. Effect of benzylaminopurine and thidiazuron on in vitro shoot proliferation of Tilia cordata Mill., Sorbus aucuparia L. and Robinia pseudoacacia L. Biol. Plant. 29:425429

Davis, J.M. and D.E. Keathley. 1985. Regeneration of shoots from leaf disk explants of black locust, Robinia pseudoacacia L. Proc. 4th North Central Tree Improvement Conf., East Lansing, Mich. p. 29-34.

Davis, J.M. and D.E. Keathley. 1987. Differential responses to in vitro bud culture in mature Robinia pseudoacacia L. (black locust). Plant Cell Rpt. 6:431-434.

Davis, J.M. and D.E. Keathley. 1988. In vitro propagation of a black locust tree with an unusual phenotype. Nitrogen Fixing Tree Res. Rpt. 6:65-67. and organogenesis. Planta 167:473-481.

Table 4. Effect of growth regulators and organic $\mathrm{N}$ sources on shoot formation in black locust leaf cultures. Explants were cultured for 30 days on MS medium containing one of several organic $\mathrm{N}$ sources and supplemented with IBA and BA, then transferred to the same medium without growth regulators or with $B A$ and IAA. Values are means of three replications with four explants each.

\begin{tabular}{|c|c|c|c|c|c|c|}
\hline \multicolumn{2}{|c|}{ Growth regulators $\left(\mu_{M}\right)$} & \multicolumn{4}{|c|}{ Organic N source ${ }^{2}$} & \multirow[b]{2}{*}{ Mean $^{y}$} \\
\hline Initial culture & Subculture & None & $\mathrm{CH}$ & $\mathrm{G}(10 \mathrm{~mm})$ & $\mathrm{G}(20 \mathrm{~mm})$ & \\
\hline \multicolumn{7}{|c|}{ Caulogenic explants (\%) } \\
\hline \multirow[t]{2}{*}{ BA/IBA $(4.4 / 9.8)$} & None & 76.7 & 66.7 & 25.0 & 0.0 & \\
\hline & BA/IAA $(4.4 / 0.6)$ & 78.3 & 58.3 & 58.3 & 33.6 & \\
\hline \multirow[t]{3}{*}{ BA/IBA $(4.4 / 24.6)$} & None & 61.1 & 52.8 & 0.0 & 0.0 & \\
\hline & BA/IAA $(4.4 / 0.6)$ & 88.9 & 72.2 & 50.0 & 30.6 & \\
\hline & Mean $^{x}$ & $76.2 \mathrm{~b}$ & $62.5 \mathrm{~b}$ & $33.3 \mathrm{a}$ & $16.0 \mathrm{a}$ & \\
\hline \multicolumn{7}{|c|}{ Mean no. shoots/explant } \\
\hline \multirow[t]{2}{*}{$\mathrm{BA} / \mathrm{IBA}(4.4 / 9.8)$} & None & 1.6 & 1.0 & 1.8 & 0.0 & $1.1 \mathrm{a}$ \\
\hline & BA/LAA $(4.4 / 0.6)$ & 3.7 & 1.8 & 2.3 & 0.5 & $2.1 \mathrm{a}$ \\
\hline \multirow[t]{3}{*}{ BA/IBA $(4.4 / 24.6)$} & None & 1.7 & 1.0 & 0.0 & 0.0 & $0.7 \mathbf{a}$ \\
\hline & BA/IAA $(4.4 / 0.6)$ & 9.1 & 6.4 & 1.8 & 1.7 & $4.8 \mathrm{~b}$ \\
\hline & $\operatorname{Mean}^{x}$ & $4.0 \mathrm{~b}$ & $2.5 \mathrm{ab}$ & $1.5 \mathrm{a}$ & $0.6 \mathrm{a}$ & \\
\hline
\end{tabular}

${ }^{\mathrm{x}} \mathrm{CH}=$ casein hydrolyzate; $\mathrm{G}=$ glutamine.

'Interaction of growth regulators in the initial culture $\times$ growth regulators in the subculture medium. Mean separation for each entry by Tukey's test $(P \leq 0.05)$.

${ }^{x}$ Effect of $\mathrm{N}$ source. 
Table 5. Analysis of variance for Table 4 data.

\begin{tabular}{|c|c|c|c|}
\hline \multirow[b]{2}{*}{$\begin{array}{l}\text { Source of } \\
\text { variation }\end{array}$} & \multirow[b]{2}{*}{ df } & \multicolumn{2}{|c|}{ Mean square } \\
\hline & & $\begin{array}{c}\text { Caulogenesis } \\
(\%)\end{array}$ & $\begin{array}{c}\text { Mean no. } \\
\text { shoots }\end{array}$ \\
\hline Organic N source (A) & 3 & $5997.0^{* *}$ & $26.8^{* *}$ \\
\hline Growth regulators in initial medium (B) & 1 & $234.0^{\text {Ns }}$ & $15.2^{*}$ \\
\hline Growth regulators in subculture medium (C) & 1 & $6248.1^{* *}$ & $77.5^{* *}$ \\
\hline$A \times B$ & 3 & $159.1^{\text {Ns }}$ & $9.6^{\mathrm{NS}}$ \\
\hline$A \times C$ & 3 & $477.4^{\mathrm{Ns}}$ & $9.0^{\mathrm{Ns}}$ \\
\hline $\mathrm{B} \times \mathbf{C}$ & 1 & $487.5^{\mathrm{Ns}}$ & $28.8^{* *}$ \\
\hline$A \times B \times C$ & 3 & $129.2^{\mathrm{Ns}}$ & $3.5^{\mathrm{Ns}}$ \\
\hline Error & 80 & 271.0 & 3.6 \\
\hline
\end{tabular}

ss,",**NNonsignificant or significant at $P \leq 0.05$ or 0.01 , respectively.

Dhawan, V. and S.S. Bhojwani. 1985. In vitro vegetative propagation of Leucaena leucocephala (Lam.) de Wit. Plant Cell Rpt. 4:315318.

Fasolo, F., R.H. Zimmerman, and I. Fordham. 1989. Adventitious shoot formation on excised leaves of in vitro grown apple cultivars. Plant Cell Tissue Organ Cult. 16:75-87.

Gresshoff, P.M. and C.H. Doy. 1972. Development and differentiation of haploid Lycopersicon esculentum (tomato). Planta 107:161-170.

Han, H.K. and D.E. Keathley. 1989. Regeneration of whole plants from seedling-derived callus of black locust (Robinia pseudoacacia L.). Nitrogen Fixing Tree Res. Rpt. 7: 129-131.

Horsch, R.B., J.E. Fry, N.L. Hoffman, D. Eichholtz, S.G. Rogers, and R.T. Fraley. 1985. A simple and general method for transferring genes into
Mitchell, C.P. 1988. The world perspective, p. 235255. In: R.C. Hummel, W. Palz, and G. Grassi (eds.). Biomass forestry in Europe: A strategy for the future. Elsevier Applied Science Publishers, Barking, England.

Mohamed, M.F., P.E. Read, and D.P. Coyne. 1992. Plant regeneration from in vitro culture of embryonic axis explants in common and tepary beans. J. Amer. Soc. Hort. Sci. 117:332-336.

Murashige, T. and F. Skoog. 1962. A revised medium for rapid growth bioassays with tobacco tissue culture. Physiol. Plant. 15:473-497.

Ranney, J.W., A.R. Ehrenshaft, P.A. Layton, W.A. McNabb, and L.L. Wright. 1988. Short rotation woody crops program annual progress report for 1987. Oak Ridge Natl. Lab., Oak Ridge, Tenn. Rpt. ORNL 6440.

plants. Science 227:1229-1231.
Ishii, K. 1986. In vitro plantlet formation from adventitious buds on juvenile seedlings of Hinoki cypress (Chamaecyparis obtusa). Plant Cell Tissue Organ Cult. 7:247-255.

Korban, S.S., P.A. O'Connor, and A. Elobeidy. 1992. Effects of thidiazuron, naphthaleneacetic acid, dark incubation and genotype on shoot organogenesis from Malus leaves. J. Hort. Sci. 67:341-349.

Lloyd, G. and B. McCown. 1980. Commerciallyfeasible micropropagation of mountain laurel, Kalmia latifolia, by use of shoot-tip culture. Combined Proc. Intl. Plant Prop. Soc. 30:421427.

Merkle, S.A. and A.T. Wiecko. 1989. Regeneration of Robinia pseudoacacia via somatic embryogenesis. Can. J. For. Res. 19:285-288.
Schenk, R.V. and A.L. Hildebrandt. 1972. Medium and techniques for induction and growth of monocotyledonous and dicotyledonous plant cell cultures. Can. J. Bot. 50:199-204.

Systat. 1992. Systat 5.2. Systat, Evanston, Ill.

Tabone, T.J., P. Felker, R.L. Bingham, I. Reyes, and S. Loughrey. 1986. Techniques in the shoot multiplication of the leguminous tree Prosopis alba clone B2 V50. For. Ecol. Mgt. 16:191-200.

Tukey, J.W. 1953. Some selected quick and easy methods of statistical analysis. Trans. New York Acad. Sci. ser. II 16:88-97.

Wright, M.S., D.V. Ward, M.A. Hinchee, M.G. Cames, and R.J. Kaufman. 1987. Regeneration of soybean (Glycine max L. Merr.) from cultured primary leaf tissue. Plant Cell Rpt. 6:8389. 